\title{
Морозова Н.Э. \\ Основы организационных конфликтов и пути их разрешения в образовательной среде по схеме педагог-педагог
}

ФГБОУ ВО "Новгородский государственный университет имени Ярослава Мудрого" (Россия, Великий Новгород)

doi: $10.18411 / \mathrm{j}-06-2021-181$

\section{Аннотация}

В статье поднимается вопрос о конфликтах в педагогической среде между работниками, очагами их возникновения и способы их разрешения. Рассматривается понятие и суть организационного конфликта.

Ключевые слова: образовательное учреждение, организационный конфликт, взаимодействие, информационный мир, новшества, профессиональный уровень.

\section{Abstract}

The article raises the question of conflicts in the pedagogical environment between employees, the centers of their occurrence and ways of resolving them. The concept and essence of organizational conflict is considered.

Keywords: educational institution, organizational conflict, interaction, information world, innovations, professional level.

В современной образовательной меняющейся образовательной среде не полностью рассмотрен вопрос о конфликтах в учебной обстановке на рабочем месте.

Стоит обратить внимание на основное - "организационный конфликт". Начнем с определения, педагогический конфликт - это межличностное взаимодействие участников учебного процесса форма проявления противоречий, вызывающих негативный фон общения.

Исследованы особенности данного конфликта, среди них можно выделить:

- поведение в конфликте определяет социальный статус;

- осознанная ответственность педагога за свои решения;

- разница в жизненном и профессиональном опыте участников конфликта;

Следовательно, педагогические конфликты проще предупредить, чем разрешить. Данный вопрос необходимо изучать и искать пути их разрешения.

В классификации педагогических конфликтов выделяется "конфликт взаимодействий". Заключается он в возникновении причин не объективного характера, а личностных особенностей, ценностных приверженностей, эмоционального состояния.

Организационный конфликт возникает из-за несовершенства организационных структур и системы управления в образовательной среде, неопытность и непрофессионализм педагогических работников на предмет знаний о способах устранения конфликтов или его не возникновения.

Чаще всего эти конфликты проявляются в неполном или недостаточном присутствии преемственности в содержании и организации основных этапов учебного процесса.

Также стоит отметить, непродуманные и низко продуктивные педагогические новшества. Низкая организация и адаптация молодых специалистов в самом педагогическом коллективе. Зачастую молодые специалисты становятся в помощь преподавателю, молодой специалист не может привнести что то новое, он вынужден выполнять задания и помогать более старшему педагогическому работнику учреждения. В дальнейшем, такой специалист становится лишь продолжателем той 
системы с которой работал все это время и не может внести новые новшества, технологические новинки в обучении.

Также встречается непрофессионализм организационных структур образовательного учреждения и их донесения информации до педагогов.

Рассмотрим организационный конфликт по схеме:

ПЕДАГОГ $\longrightarrow$ ПЕДАГОГ

Чаще всего, мы можем встретить в образовательной организации личностный конфликт между педагогическими работниками.

Основные причины:

1) недостаточная компетентность педагогов;

2) чрезмерно эмоциональная реакция педагога на оценку своих личных или профессиональных качеств;

3) тревога, психологическое неустойчивое состояние, усталость.

Практика показывает, что чаще всего в основе конфликтов в организации является возрастное различие педагогов, тем самым разница в опыте, также конфликты появляются с среди работников образовательного учреждения те у кого есть постоянное рабочее место (кабинет) и те, у кого нет и педагог вынужден переходить в разные кабинеты (аудитории).

Стоит отметить и личную несобранность и неорганизованность педагога, неполное знание своих должностных обязанностей и непродуманное организация самой организации в обеспечении рабочих мест.

Сегодня в образовательной среде происходят большие изменения. Меняются и сами подходы к обучению, что требует от специалистов более опытного класса и молодых педагогов перестраиваться на новый информационный мир.

Меняется нормативная база, что требует повышения своего профессионального уровня. Путь разрешения конфликтов лежит в правильном построении организационной структуры в образовательном учреждении. Рост профессионализма и успешность прохождения различных обучающихся курсов, возможность внедрения и передачи своих знаний. Практика показывает, что современные руководители учреждений должны повышать свой уровень и уровень всего педагогического состава о конфликтах и их управлении.

\section{$* * *$}

1. Ведущий образовательный портал России "Центр Развития Педагогики", курс "Конфликты в образовательной среде" https://infourok.ru

2. Клименских М.В., Ершова И.А Педагогические конфликты в школе. - М.: Учебное пособие, Издательство Уральского университета, 2015. - С. 6

3. Волков К.Н. Психологи о педагогических проблемах. - М.: Просвещение, 1991. - С. 68

4. Кала У.В., Раудик В.В. Психологическая служба в школе. - М.: «Знание», 1996. - С. 267

5. Чернышев А.С. Практикум по решению конфликтных педагогических ситуаций. - М.: Российское педагогическое агентство, 1998. - С. 46

\section{Муллер О.Ю., Боталова А.Н. \\ Содержательная характеристика понятия «экономическая компетентность студентов педагогического направления»}

Сургутский государственньй университет (Россия, Сургут)

doi: 10.18411/j-06-2021-182

Аннотация

В статье рассматриваются подходы относительно определения понятий «компетенции», «компетентность», «профессиональная компетентность». На их 